\title{
1. Copyright in common law jurisdictions
}

\subsection{INTRODUCTION}

There are, as noted in the Introduction, several problems that explain the inglorious predicament of copyright law and policy.

First is the fact that a system used to regulate mostly trade in, and use of, physical products (books, records, copies of motion pictures on $35 \mathrm{~mm}$ film, etc.), the production and distribution of which was managed by professionals (professional authors, record companies, film producers, broadcasters, etc.) whose business included dealing with and transacting over copyright (in the same way that corporations deal with complex tax and employment laws as a matter of necessity if not exactly jubilation), has had a dual change of target. The first facet of the change is that the nature of the technology used to create and disseminate copyright works has changed radically. Most of it is now done online, and controlled by a host of players who do not see themselves as copyright holders but rather as providing or enhancing access to 'content', often in exchange not for monetary payment but for pushing targeted ads on users. The second facet of the change is that the technology allows users to engage in a much more proactive way with copyright content, by making it available to others (e.g., via social media), modifying it, commenting on it, etc. In other words, the regulatory vehicle has barely evolved but it is not used on the paved roads for which it was conceived but rather on a rocky path of rapid technological evolution.

A second set of problem is more technical in nature, yet is it also a fundamental aspect in need of reform. It is the fact that copyright is not truly a right but rather a complex bundle of 'right fragments' that differ from country to country in number, scope and nature despite the existence of binding international norms that have led to some degree of harmonization. The rights fragments are generally expressed in terms of the technical nature of the use made of the work, not its purpose or whether the use has any value. For example, the right of reproduction, which lies at the core of the copyright edifice, is often read as implying that any copy of copyright material is prima facie infringing. Lawmakers and courts have long 
recognized that this makes no sense and have carved out many forms of reproductions that happen by the billions every day, such as temporary or transient copies made when a work is transmitted online.

A great-if perhaps not very serious-illustration of this is the 'Kopimashin' created by the The Pirate Bay's co-founder. The machines made 100 copies per second of Gnarls Barkley's 'Crazy' but then deleted them even as they were created. As Cory Doctorow put it, the machine has 'an LCD screen that calculates a running tally of the damages [...] inflicted upon the record industry through its use. The 8,000,000 copies it makes every day costs the record industry $\$ 10 \mathrm{~m} /$ day in losses' ${ }^{12}$ It is quite obvious that this activity causes not a penny of losses for anyone. Yet it would likely be considered 'massive copying' under current copyright laws.

This is a symptom of a much greater malaise, namely that the way in which rights are formulated is no longer well-connected to actually relevant forms of use. It is like using a surgeon's scalpel to open a can of tuna. You can get there, but there are better ways. Making matters worse, the rights fragments expressed in terms of technical uses (reproduction or copying, performance in public, adaptation, communication to the public, etc.) do not map over the exceptions and limitations (E\&Ls), which are often expressed either as purpose-specific (e.g., libraries may make copies for preservation purposes) or as open-ended tests left for courts to define a range of permitted uses (e.g., fair dealing and fair use).

This first chapter explores these deficiencies against the backdrop of the evolution of copyright in common law jurisdictions, such as Australia, Canada, New Zealand, South Africa, the UK and the US to name just a few. This chapter presents two structural problems using mostly common law jurisdictions as exemplars. Chapter 2 will continue the analysis from a broader geographic approach.

\subsection{THE STATUTE OF ANNE}

Let us begin with a bit of history. For common law countries, it is generally thought that the first copyright statute is the Statute of Anne (1709-10). There is a debate surrounding the exact intentions of the British Parliament when it was enacted. On the one hand, the statement: 'for the

12 Cory Doctorow, Pirate Bay co-founder invents an infernal device that will utterly bankrupt the music industry, Boingboing.net, 22 December 2015 (available at <http://bit.ly/1Seczn3> accessed 23 December 2015). 
Encouragement of learned Men to compose and write useful Books. . .' in the Statute's title suggests that it was partly enacted with the public good in mind. Some scholars even go so far as to argue this was the primary intention. ${ }^{13}$ On the other hand, the enactment was clearly in reaction to pressure from publishers seeking to legitimize their self-regulation, combined with the government's quest to maintain some sort of monopolistic publishing market. ${ }^{14}$

This dual objective had previously been achieved by combining a ban on the importation of foreign books (in $1534^{15}$ ) and the grant by Queen Mary of a Charter to the Stationer's Company (in 1556). The Stationers' (publishers) Charter allowed them to search out and destroy any book printed in contravention of the Statute of Proclamation. Because entries in the Company's register were restricted to Company members, only books licensed by the Stationers could be registered and legally printed in the UK. This served both the interests of publishers and of the Crown, which maintained a degree of control over new publications. The system was enforced both through the Star Chamber and, for Elizabeth and her Stuart successors, with assistance from the Church, no doubt a reflection of the deep religious struggles of that period. ${ }^{16}$ The Stationers' privileges lapsed in 1679. While King James revived it for seven years in 1685, it could not last long in the political climate of his dethronement. Parliament finally refused to renew it in 1694.

The policy discussions that led to the adoption of the Statute of Anne were informed by the work of authors and scholars such as John Milton ${ }^{17}$ (English poet, best known for his epic, Paradise Lost) and John Locke (English philosopher and physician regarded as one of the most influential thinkers of the Enlightenment) who were instrumental in the fight to put

13 Ronan Deazley, On the Origin of the Right to Copy, Charting the Movement of Copyright Law in Eighteenth-Century Britain (1695-1775) (Hart Publishing 2004) 226.

14 L Ray Patterson, Copyright in Historical Perspective (Vanderbilt UP 1968) 8, 143.

15 As a point of reference, Caxton introduced the printing press into England in 1476, 26 years after its invention by Gutenberg.

16 James I also issued 'printing patents', in the same form as letters patent concerning 'inventions' to certain publishers, but most were issued to Company members. But those patents were limited in time and thus much less important than the unlimited stationers 'copyright'. The censorship element was reinforced by various decrees of the Star Chamber issued in 1566, 1586 and 1637. See Patterson (n 14) 6.

17 See his Areopagitica (1644) reprinted in Areopagitica: A Speech of Mr. John Milton for the Liberty of Unlicensed Printing, to the Parliament of England (New York, Grolier Club 1890). 
an end to the Stationers' 'licensing' regime, which they considered as a form of prepublication censorship. ${ }^{18}$ Milton's name is often used in the history of copyright to refer to the contract by which he transferred all rights to Paradise Lost for $£ 20$. That contract is used as evidence both that authors were entitled to proprietorship in their work and that publishers were treating authors unfairly.

Locke's name is used to justify extensive copyright protection as a natural property right flowing from an author's labour. Locke favoured a temporary exclusive right for authors in literary works for the life of the author plus 50 or 70 years. ${ }^{19}$ He seemed to have less sympathy toward the publishers' monopoly. ${ }^{20} \mathrm{He}$ was also aware of the need for new material to enrich the public domain:

I know not why a man should not have liberty to print whatever he would speak. . .

That any person or company should have patents for the sole printing of ancient authors is very unreasonable and injurious to learning; and for those who purchase copies from authors that now live and write, it may be reasonable to limit their property to a certain number of years after the death of the author, or the first printing of the book, as, suppose, fifty or seventy years. This I am sure, it is very absurd and ridiculous that any one now living should pretend to have a propriety in, or power to dispose of the propriety of any copy or writings of authors who lived before printing was known or used in Europe.

Locke died in 1704 as new proposals for a first 'copyright' statute were being discussed. The Statute of Anne, which granted 'authors and their

18 Mark Rose, Authors and Owners: The Invention of Copyright (Harvard UP, 1995) 28-32.

19 John Locke, Memorandum, King, 203, 208-9.

20 In a letter to a member of Parliament, B Rand, Correspondence of John Locke and Edward Clarke, at 39 (org.1927 rep.1975), he wrote:

By this monopoly also of those ancient authors, nobody here, that would publish any of them anew with comments, or any other advantage, can do it without the leave of the learned, judicious stationers. For if they will not print it themselves nor let any other, by your labour about it never so useful, and you have permission to print it from the Archbishop and all the other licencers, it is to no purpose. If the company of stationers so please it must not be printed. An instance you have of this in Æsop's Fables. Pray talk with A. Churchill concerning this who I believe will be able to show you other great inconveniences of that act, and if they can possibly, I wish they could be remedied. And particularly, I think, that clause, where printing and importation of any books, to which any have a right by patent is prohibited, should be at least thus far restrained that it should be lawful for anyone to print or import any Latin book whose author lived above a thousand years since. 
assigns' the sole right and liberty of printing books for a period of 14 years from first publication, ${ }^{21}$ was finally granted Royal Assent on 5 April 1710. The fact that the Statute granted the right not only to the Stationers but also to the authors - a major difference from the Stationers' monopoly that was in place until 1694 - was the direct result of the Stationers' reliance in their petition to Parliament on a 'natural' right of authors in their works. This was part of a pan-European strategy of publishers at the time. ${ }^{22}$ Focusing the attention on authors allowed booksellers to achieve their aims while avoiding the problem of defending their unpopular trade monopoly. ${ }^{23}$ That said, to see the author merely as an excuse to grant an exclusive right on books would be an oversimplification. ${ }^{24}$ Authors did want rights they could enforce themselves, even though many of them were reasonably happy to work with the publishers. An argument that authors used at the time was that if they had an obligation not to write defamatory or otherwise 'unacceptable' (in the eyes of the authorities) material, then authors should have a coextensive antipodal right in their writings.

Put differently, there was a timely convergence of interests between authors and publishers. On the one hand, authors were basking in the sun of the Enlightenment, stroked by the rays of individualism. ${ }^{25}$ On the other,

21 A second term of 14 years was possible if the author was still alive.

22 See Roger Chartier, 'Figures of the Author', in Brad Sherman and Alain Strowel (eds), Of Authors and Origins: Essays on Copyright Law (OUP 1994).

23 See Patterson, (n 14) 169; and Jon M Garon, 'Normative Copyright: A Conceptual Framework for Copyright Philosophy and Ethics' (2002) 88 Cornell Law Review 1278, 1298.

24 As Professor Bently cautioned:

... it is often said that a natural-rights-based justification for copyright inevitably produces a different conception of copyright than is produced by an incentive argument. More specifically, it is argued that a natural rights conception of copyright leads to longer and stronger protection for authors (and copyright holders) than an incentive-based conception. This is because a natural rights argument for copyright is assumed to result in a form of property that is perpetual and unqualified. In contrast, an incentive-based argument only justifies the grant of the minimum level of protection necessary to induce the right-holder to create and release the work. [...]

While it is understandable that lobby groups use (or abuse) the various justifications to further their ends, more problems arise when people begin to believe the rhetoric. ... $33-4$.

Lionel Bently and Brad Sherman, Intellectual Property Law, (OUP 2001)

25 Michel Foucault commented that the modern concept of author 'constitutes a privileged moment of individualism in the history of ideas'. Michel Foucault, 'What is an Author?', in J Harari (ed.) Textual Strategies: Perspectives in 
the Stationers advocated in favour of a right for authors of which they would be the assignees, through the then-prevailing patronage arrangements. They understood that they needed a justificatory theory other than greed or, indeed, their desire to survive to convince both Parliament and the public.

The Statute of Anne was not the first recognition of 'author's rights' in the United Kingdom. A common law right had been recognized decades earlier. Nor was it the first appearance of authors' rights internationally. The role of the author as holder of a 'right' in the products of her intellectual work had emerged in France almost a century earlier. A French court granted the equivalent of an injunction to prevent an almanac being sold without the consent of its author. ${ }^{26}$ The court's reasoning was close to modern trade-mark/passing off principles in that it was afraid the author's reputation might suffer if a book with his name on it was published without his consent. Yet this case, and the many cases that would follow, support Mark Rose's observation that:

[In] the early modern period, in connection with the individualization of authorship. .., there developed a general sense that it was improper to publish an author's text without permission. The acknowledgement of an author's interest in controlling the publication of his texts is not necessarily the same as the acknowledgment of a property right in the sense of an economic interest in an alienable commodity. ${ }^{27}$

One might speak more of propriety than property in such a context. Chapter 2 continues this discussion by presenting the emergence of author's rights internationally.

\subsection{IMPACT OF THE STATUTE}

The entry into force of the Statute in 1710 raised the question whether it abolished or superseded extant common law copyright. Before the Statute, common law copyright had been used mostly to prevent the first publication of a work without the author's consent, which was also the law in civil law jurisdictions. Only after its first publication did the book enter the (different) realm of commercial exploitation. Authors and publish-

Post-Structuralist Criticism (Cornell UP 1979) 141. See also Peter Jaszi, 'On the Author Effect: Contemporary Copyright and Collective Creativity' (1992) 10

Cardozo Arts and Entertainment Law Journal 293.

26 Rose (n 18) 17-19.

27 Ibid., 18. 
ers tried to convince various courts that the Statute had not superseded the pre-existing, perpetual common law copyright. Scottish booksellers who were happy to reprint 'public domain' English titles ${ }^{28}$ argued that, if common law copyright ever existed, it could not no longer be enforced after the expiry of the statutory monopoly.

But authors had strong supporters. The Stationers supported efforts by authors to have perpetual property rights vested in authors recognizedprovided those rights would be assigned to them. Alexander Pope, the famous British poet and translator of Homer's Iliad and Odyssey, was also one of most active advocates for the English author community at the time. His famous court case against the controversial English publisher Edmund Curll ${ }^{29}$ (in part because he published a few books considered pornographic) is considered a major precedent still today. ${ }^{30}$ Curll had published a series of letters he had bought on various subjects written by several authors, including Pope. This publication was unauthorized. Quite importantly for our purposes, it was probably the first case that clearly separated as a legal matter the tangible property in the letter (belonging to the recipient) and the author's property in the (intangible) content, an important abstraction. After doing so, the Court was able to rule in Pope's favour.

The case highlighted the divide between those who advocated authorial rights in the broadest sense and those who preferred to limit common law rights to unpublished content. ${ }^{31}$ Indeed, a number of injunctions had been issued in the Chancery to stop unpublished manuscripts from being published. ${ }^{32}$ The question was whether common law judges could be convinced to go in the same direction.

28 See Millar v Kinkaid (1750), 4 Burr 2319, 98 ER 210.

29 Pope v Curll (1741) 1 Ark 341.

30 See Pat Rogers, 'The Case Pope v Curll' (1972) The Library: Transactions of the Bibliographical Society 27, 326-31.

31 To further demonstrate the importance of British copyright history on US (state) common law copyright, one could cite s 985 of the California Civil Code, which is directly inspired by Pope v Curll. It provides as follows: 'Letters and other private communications in writing belong to the person to whom they are addressed and delivered; but they cannot be published against the will of the writer, except by authority of law.' It is fairly apparent that the writer's right to prohibit is not a 'property' right.

32 As noted by Professor Patterson, several orders of the Court of Assistants made it clear that the stationers had to show they had the author's consent. See Patterson (n 14) 69. However, authors themselves could not copyright. With respect to published works, it was a publisher's right only until the Statute of 1709 . See ibid., 5 . 
In Tonson v Collins, ${ }^{33}$ Benjamin Collins, a bookseller, tried to prevent the defendant from reprinting copies of a work he owned. The case was heard en banc (by all available common law judges). ${ }^{34}$ There was agreement among the parties that authors were protected at common law (without the intervention of the Statute, therefore) from any unauthorized first publication of their work. The disagreement focused squarely on whether common law copyright in published works survived the enactment of the Statute of Anne and if so, to what extent. The outcome of the case was inconclusive $^{35}$ but it allowed Lord Mansfield, who acted as barrister on behalf of plaintiffs, to enunciate pro-copyright views. This is important because Lord Mansfield became Chief Justice of King's Bench a few years later, and authored a key opinion in the famous Millar v Taylor ${ }^{36}$ case. He ruled that the author's common law copyright existed in perpetuity both in published and unpublished works, it is just that an author should reap the pecuniary profits of his own ingenuity and labour. ${ }^{37}$ It is just, that another should not use his name, without his consent. It is fit that he should judge when to publish, or whether he will ever publish'. ${ }^{38}$ In this brief quote, we find three of the four components of modern copyright, namely: the right to control economic exploitation of the work; the right to prevent its publication; and the 'moral right' not to see one's name used without consent.

The question of common law copyright surviving the Statute of Anne did not die until Donaldson v Becket. ${ }^{39}$ Thomas Becket (not to be confused with the twelfth century Archbishop of Canterbury) and a group of booksellers who had obtained the rights to The Seasons and other poems obtained an injunction in Chancery against Edinburgh bookseller Alexander Donaldson, who had reprinted the poems after the expiration of statutory protection. The case made its way to the peers, who ended up overturning the injunction and deciding that no common law copyright in published works had survived the Statute of Anne. But a narrow victory it was. On the question of whether the common law copyright survived

\footnotetext{
331 Black W 301(1761), 96 ER 169.

34 King's Bench, Common Pleas and Exchequer.

35 In fact, the case was dismissed for collusion between the parties. Apparently, a pact had been made to get the court to recognize the author's perpetual common law right. See Patterson (n 14), 165-7.

36 (1769) 4 Burr 2303, 98 ER 201.

37 Terms which will reappear in the early twentieth century, when the notion of 'originality' will be defined by UK courts.

3898 ER 201, 252.

39 (1813) 2 Brown's Parliamentary Cases (2nd edn) 129, 1 ER 837; 4 Burr 2408,
} 98 ER 257. 
authorized publication, the common law judges - who had been asked to provide their opinion to the peers (who, in those days, all voted, lawyers and laymen alike) - voted six to five against the right. ${ }^{40}$ By 1770 , it was thus clear that there was a common law right only to prevent first publication, and a separate statutory right that prevented reprinting of a book for 14 years - a term which would eventually be extended. In reaching this conclusion, arguments based on moral impropriety had at least as much weight in swaying Parliament and the courts as labour-based narratives. Professor Brad Sherman's work has shown ${ }^{41}$ that the subsequent evolution of copyright law in the UK during the nineteenth century ${ }^{42}$ was that of a system open to influences of emerging international norms ${ }^{43}$ and developments in Prussia, Saxony and France.

\subsection{MORE RECENT EVOLUTION OF COPYRIGHT IN COMMON LAW JURISDICTIONS}

Copyright in this 'original' version was a right to prevent copying for limited times. Authors and publishers of theatrical plays and music were at disadvantage because most of the economic value of their material was created when the play was performed, not when it was copied. Thus a parallel right to prevent the performance in public was eventually added. What followed between the mid-eighteenth century and the early 1990 s, i.e., approximately 250 years, is a process of haphazard historical accretions: each time a new form of creation (i.e, cinema) or dissemination (i.e., radio, television, cable, satellite) was invented, copyright was adapted through court decisions, amendments to national laws and new international treaties, such as the 1994 TRIPS Agreement concluded as a part of WTO Uruguay Round of global trade talks (1986-94). New 'rights fragments' were added to the 'bundle' of rights, which now includes reproduction, public performance/communication to the public, adaptation and translation (a rough equivalent of the right to 'make derivative

\footnotetext{
40 According to Professor Rose, the vote was actually six top five in favour of the authors but was not reported correctly. See Rose, (n 18) 98-111.

${ }_{41}$ See Brad Sherman, 'Remembering and Forgetting: The Birth of Modern Copyright Law' (1995) 10 IPJ 1.

42 If it ever was. Authorial advocates were fully aware of Kantian and natural rights justifications used on the Continent, as is apparent in Defoe's writings, among others.

43 Including both bilateral treaties and the Berne Convention. See Sherman (n 41) 8-12.
} 
works' in the US statute), rental, sometimes a lending right and a droit de suite (resale right for works of fine art). Not all such fragments exist in all countries, nor are they identical in scope or called the same way. Very often, each rights fragment is owned by or licensed to a different 'rights holder', and each fragment may itself be assigned or licensed often for each territory, langue, etc. The result is a complex matrix of rights, which itself changes through time.

While one could discuss whether each such change to the initial framework of copyright was adequate (such as the addition of computer programs to the category of 'literary works' - a form of protection now mostly viewed as inadequate both doctrinally and normatively), which is easier to do a posteriori, the fact remains that for 300 years or so copyright was designed as a mechanism to regulate relations among professionals (authors, publishers, distributors and professional users) who could handle a certain degree of complexity. More importantly perhaps, prior to 1995 , most users only needed one right fragment for example, the reproduction right to make copies of books or CDs, or the right of public performance to perform a play or music in public. Absent an exception, on the Internet one needs at least two fragments: reproduction (on the computer/server) and communication to the public (part of the right of public performance in the United States). If an adaptation or translation is required, a third right fragment is required. If multiple territories are involved (which is the default case of the Internet), one may need to license or acquire multiple rights fragments in each territory. This will typically involve multiple licensing transactions. Each transaction will necessarily involve costs (for all parties). In addition, the owner (or licensee) of each fragment may try to get the lion's share economic value of the entire licensed operation, even though the fragment owned or exclusively licensed to that person is only one of many needed.

A case in point is the licensing of radio broadcasting. In the past broadcasters only needed to license the communication to the public fragment and many national laws allowed them to make unlicensed 'ephemeral recordings' without a separate reproduction license. The law recognized the dominant fragment as being the performance/communication, as it were, and paid little heed to the temporary copy that may be made by the broadcaster. But in the age of digital broadcasting, more or less permanent copies of songs are made on servers operated by or for the broadcaster and owners of the reproduction fragment of musical works in many countries are now trying to license the copying of music by broadcasters, at a price which would be added to the existing broadcasting (communication) licenses.

To explain this key point from a different perspective, prior to 1995 copyright was a right used by and between professionals, with discrete 
rights fragments corresponding (more or less) to identifiable uses or users. End uses and users did not matter. For example, no one had to sign a license agreement when buying or borrowing a book or a CD. Indeed, many countries had specific exceptions for end-user use, such as private copying and this inapplicability of copyright, recognized by law, was often 'compensated' by levies on blank media or recording equipment or blanket licenses used for, e.g., photocopying. That is no longer the case. Copyright is now a tool used against individual end-users, trying to prevent them from using copyrighted material beyond boundaries set by right holders. Users who access online material must click-accept licensing terms in contracts of adhesion that often run 10, 20, 30 pages or more and often limit their right to use the material, and may contain waivers of exceptions such as fair use, fair dealing or private copying. Technology, in the form of Digital Rights Management, is sometimes used to enforce those restrictions technologically. In a fundamental change to the nature of copyright (at least to the extent that this right is clearly designed to target end-users), laws have been adopted in the United States (the 1998 Digital Millennium Copyright Act or DMCA), Europe (as part of 'Information Society' or InfoSoc Directive) and many other countries to prevent the circumvention of technological locks, a legislative backing of the private, non-negotiable, ordering contained in license agreements. These laws were adopted in the wake of the two WIPO treaties adopted on 20 December 1996, the WIPO Copyright Treaty and the WIPO Performances and Phonograms Treaty. Many copyright industries, in particular music and film, are understandably troubled by the unauthorized online availability of 'content'. They are thus trying to find other measures, including criminal enforcement (which implies the use of state resources) and denial of access.

The arguments of those right holders are simple and straightforward: copyright is property and by using that property without paying for it, users are 'trespassing' as it were, or, in economic terms, getting value without paying for it. Clearly, copyright industries need revenue to continue to do what they do. Interestingly, numbers published by the Recording Industry Association of America (RIAA) show that after a significant drop, revenues increased in 2003, even though unauthorized use of music doubled over the same period. RIAA numbers show that the industry had continued year-over-year increases in both wholesale and retail revenue in 2015, 2017 and 2018. A number of studies-including a detailed 2018 report by the Institute for Information Law of the University of Amsterdam (IvIR) - have also tended to demonstrate that file-sharers and other unauthorized users still buy CDs and that for some types of music and other categories of copyright material at least, unauthorized use is a form of viral advertising. Independently of the validity of those 
findings, there are no studies that show that a download equals a lost sale in every case. It is more realistic to say that some downloads are lost sales, some have no effect on sales (e.g., the user listens for a few seconds and realizes she does not like the music) and some have a positive effect. In the area of scientific and technical publishing, making content available online and cross-linking publications (including those of competitors) seems to have led to an increase in both use and revenues.

The new models upend the very notion of scarcity that had been a paradigmatic justification for many IP rights (rights to exclude meant to create scarcity). Available empirical and anecdotal data made available in recent years has confirmed my initial intuition and led me to one fairly solid conclusion: the evolution of the Internet as a market for information is counter-intuitive: value does not come from scarcity; it comes from exposure. As I wrote back in 2005, information does not have or acquire commercial value because it is scarce, but because it is found by those who value it. The corollary of this axiom is that 'content' must be available, including to those for whom it may not have value. In this scenario, thinking of copyright material as property and interpreting any access to such property as some form of trespass is clearly inappropriate. Yet, too often that is still the stated purpose of copyright policy.

The unauthoritized availability of music and video files has demonstrated beyond a doubt the inadequacy both as a matter of revenue increase for copyright holders and as a matter of privacy and personal data protection of trying to count or limit 'copies' online. Legal and technical efforts to stop to reduce file-sharing, for example, have reduced some unauthoritized activity (though often the effect was short-lived) but they often failed to increase income for right holders and also had significant public relations costs. Unauthorized use is effectively reduced only when the content was available legally online without undue use restrictions.

It is also necessary going forward to recognize the myriad ways in which consumers decide for themselves whether to pay (reducing the incentive by having a fair but paying option is useful here) by hiding technologically using USENET, proxies, TOR, etc. They may decide to get something for free to 'try' and pay later once they have determined that the object has value. This represents a shift from paying up front or ex ante, before knowing how much actual value the object has, to paying after the fact, that is, ex post valuation by individual users. This is not a song that some right holders like to hear but ignoring reality is a poor basis for policy making.

The next wave of change is three-dimensional printing. The sharing of files containing instructions to print objects protected by design rights, copyright and/or patents will induce dramatic changes. As with music and video file-sharing, however, the end of physical scarcity does not have 
to mean the end of IP, an issue other scholars have also discussed. ${ }^{44}$ The lesson is that the use and enforcement of the right must change in fundamental ways, from a power to limit or control copies to the establishment of fair remuneration flows.

Naturally, efforts to reduce copyright (and patents some might add) and - ultimately to get rid of it entirely - find favour in the world of online intermediaries. Companies that provide access to links to file-sharing sites now can provide links to sites that provide 3D printing files and sell ads in the process, without having to share profits with those who created this 'content'. This book takes the view that there are huge societal risks in allowing them to continue to do so.

Yet it is undeniable that the valuations of online intermediaries reflect the ability of Internet users to find information that one values (most). Old and new intermediaries are front and centre. Both Internet-only entities such as Google/Alphabet and ISPs, and more traditional ones (though using new tools) such as libraries and information intermediaries, have an ever greater role to play. They are information locators but also choke points, the link between millions of websites, on the one hand, and billions of users on the other. They empower new information business models. They are also an easy policy target because, if one cannot stop the Internet end-user, then why not stop the intermediary? In the US, the liability of many online intermediaries, including ISPs, was limited as part of the DMCA 'deal'. They are under various obligations to block access to infringing material ('notice and take-down') and may have to respond to right holder-issued subpoenas. Right holders have also attacked makers of software that allows Internet users to share material and individual endusers. ${ }^{45}$ Yet by targeting end-users and intermediaries, copyright holders are attacking their consumers and business partners, respectively. This is not necessarily what they teach in business schools.

This strategy had pernicious unintended effects. Widespread disregard for copyright, and the law more generally, in online behaviour patterns has led to cynicism. It may have damaged respect for the rule of law itself. Social norms justify end-users who use software that makes copyright enforcement harder to detect and enforce. Napster was a centralized database; In contrast, peer-to-peer (P2P) technologies were only programs

44 Mark A Lemley, 'IP in a World without Scarcity' (2015) 90 New York University Law Review 460.

45 Napster was based on well-identified servers which were easy to identify and shut down once the injunction issued. File-sharing services such as Grokster are based on a decentralized architecture that gets parts of files from the computers of network users and are thus much harder to locate and shut down. 
that located data on the PCs of network users; and newer technology such as proxy-based sharing and even the use of the old USENET protocol make users almost untraceable on the network. This means that more and more Internet users are shielding themselves not only from copyright law, but other laws as well, which may even have consequences for national security.

In retrospect, recent changes to copyright laws may have been rushes to judgment. In fact, countries that have not changed their laws are not doing any 'worse'. The short answer lies in occupying the information space, rather than limiting it; abandoning the property paradigm, and, yes, allowing users to 'share'. This may be done through a combination of voluntary licensing (assuming all right holders can agree), some form of collective licensing and appropriate limitations and exceptions.

\subsection{DRAWING LESSONS FROM COPYRIGHT'S HISTORY}

The brief look at history in the previous pages shows a haphazard evolution, adding new rights and subject matter and, not always in parallel, new exceptions and limitations. The history of copyright law is indeed one of progressive fragmentation along two axes. First, along a 'work' axis, to bring under the copyright umbrella new forms of creation (photography, cinematography, computer programs); second, along a right axis to create rights in respect of new uses of copyright material (radio and then television broadcasting, cable and satellite transmission, now the Internet). ${ }^{46}$ Initially, each type of use fitted rather nicely under one right (or fragment of the copyright 'bundle'): reproduction was the right for books, ${ }^{47}$ records and even compact discs; communication to the public for broadcasters, ${ }^{48}$ adaptation for novels made into movies, etc. But the Internet changed all that: making a protected work available on an Internet server is a reproduction (on the server) and a communication to the public. Holders of the 'reproduction fragment' of the copyright bundle in respect of musical works are asking for a tariff to be paid because

\footnotetext{
46 See Daniel Gervais, La notion d'auvre dans la Convention de Berne et en droit comparé (Droz 1998).

47 Of course, each fragment can itself be split. The owner of the right for the hardcover edition may not be the same as for paperback.

48 Interestingly, because they needed to make temporary copies of material to be broadcast and this involved another right, legislators in several countries opted for so-called 'ephemeral recordings'.
} 
broadcasters are making copies that go beyond the ephemeral recording exception. Exceptions to rights are being challenged. Not only can the right be exploited differently, and different fragments grouped ('subbundles'), as in the broadcasting and Internet examples above, but each of these 'rights' may be further subdivided based on language and the market where the work will be used.

Copyright is, as just noted, a bundle of rights (reproduction, public performance, communication to the public, translation, adaptation, etc.). Right fragments ${ }^{49}$ such as 'reproduction' or 'public performance' are a source of frustration for users because they no longer map out discrete uses, especially on the Internet. Put differently, a single use of a copyright work or object of a related right (e.g., performance, recording) often requires multiple authorizations (right fragments) from several different right holders. The way in which right fragments are expressed no longer matches who does what, and for which purpose, with a work or object of a related right.

As we saw in the previous section, fragmentation has its roots in the pre-Internet history of copyright (from the late seventeenth century until the 1990s - approximately 300 years), which was essentially that of the adaptation to new forms of creation (e.g., cinema, computer programs) and dissemination of copyright works (radio, then television broadcasting, cable and satellite). Copyright adapted and was able successfully to regulate new markets made possible by these new technologies because they were created by professionals who were willing and able to live with a certain degree of complexity as part of their compliance efforts. However, many of these new technologies added layers of complexity because the right fragments in the copyright bundle grew, usually by analogy, to bring new forms of use under the copyright umbrella. For example, playwrights and music composers were able to obtain rights in respect to the live performance of their works by arguing that this was their main economic use. When radio was invented, those same live performances (mostly of opera and music) were then broadcast directly to the homes of listeners. People did not attend the live performance, and the existing exclusive right of live public performance did not apply. Broadcasters were making a commercial use of the material similar to the use made by theatre or concert hall operators. It was quite logical then, to extend the right of public performance to the communication of the performance of a work

49 Fragment or fragmentation is derived from the Latin adjective 'fractus.' See Kimberly Wertenberger, 'Fractals, Mandelbrot Sets \& Julia Sets' (available at $<$ http://www.ms.uky.edu/ lee/ma502/fractals/FRACTALS.html> last accessed 22 November 2015). 
at a distance by radio (or 'Hertzian' waves). It was only a small step after that to add television and later communication by cable, satellite and the Internet. The result of this historical process is the bundle composed of 'copyright rights' we find in most national copyright laws. The complexity of transactions required for the exploitation of several types of copyright works can be illustrated as shown in Figure 1.1.

The fragmentation of copyright occurs on many different levels - of rights stemming from national laws, which recognize several economic rights (reproduction, communication to the public, adaptation, rental, etc.) within market structures, within licensing practices, within a repertory of works, within different markets (language, territory) and through the interoperability (or lack thereof) of rights clearance systems. Fragmentation has a direct impact on all affected parties, whether they be right holders, users of copyright works or regulatory authorities that oversee the process.

The inherent difficulty is perhaps best illustrated by way of examples. If a hypothetical broadcaster wanted to put music on the Internet, at least five right fragments could be involved, namely:

- reproduction on the emission server; ${ }^{50}$

- authorization of communication to the public in territory of emission;

- communication to the public in territory of reception;

- 'making available'; 51 and

- reproduction on another computer in the territory of reception. ${ }^{52}$

In fact, this rights matrix is more complex because there are three levels of rights involved in music:

- composers, songwriters and lyricists;

- performing artists; and

- makers (producers) of the sound recording.

The rights matrix is demonstrated in Table 1.1.

In short, 15 different rights analyses are required if one considers both offline and online uses. Actually, if the composer and lyricist's rights

50 Unless, at the time the copy is made, it is a 'private copy'. Even then theories based on the right of destination might apply.

51 Assuming this is considered a separate right implementing art 8 of the WIPO Copyright Treaty (1996), and arts 10 and 14 of the WIPO Performances and Phonograms Treaty (1996). This is discussed further in Chapter 5.

52 Which is also potentially a 'private copy'. 


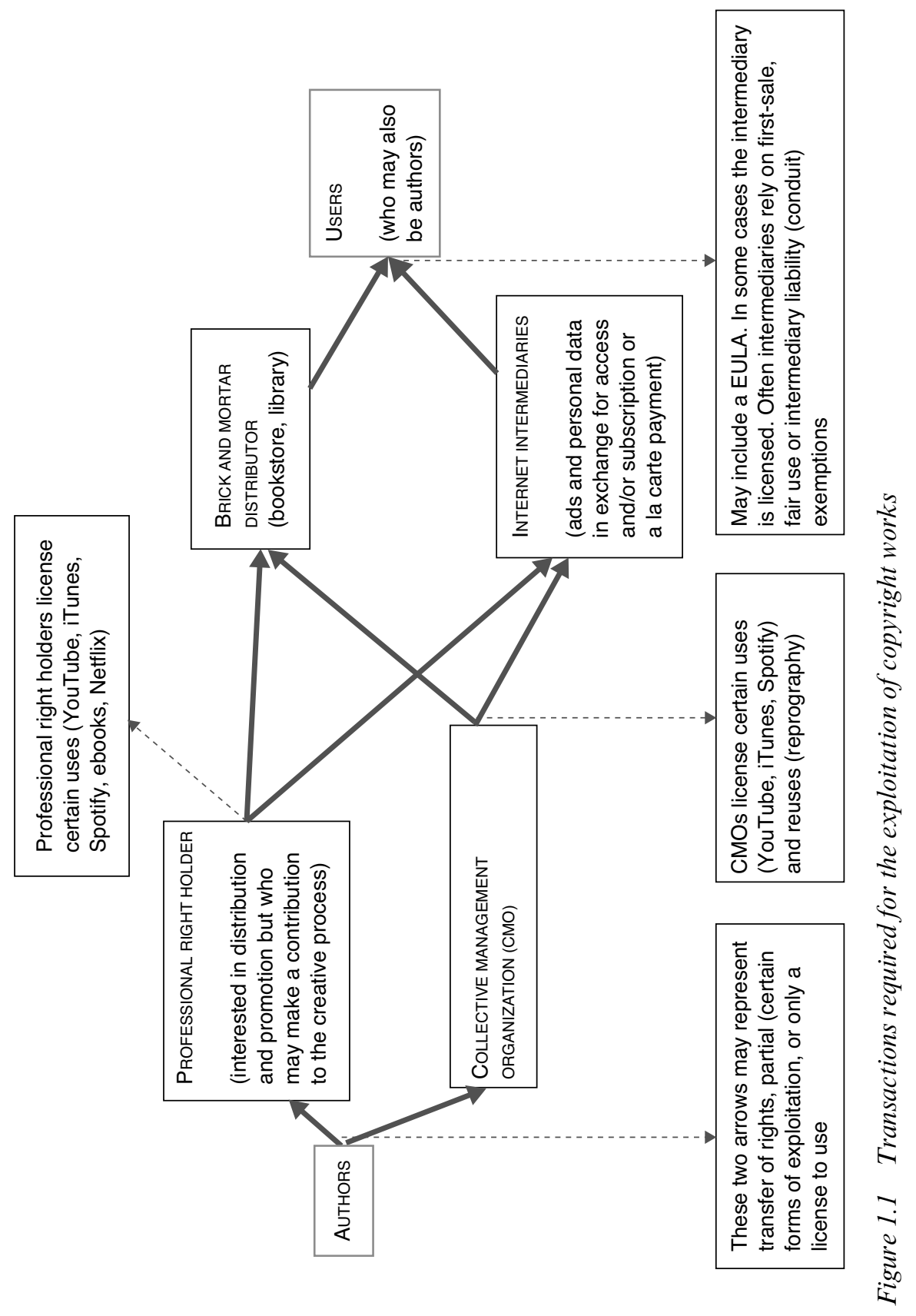


Table 1.1 Rights matrix to license a point-to-point Internet communication of a sound recording containing a performance of a protected musical work

\begin{tabular}{llll}
\hline $\begin{array}{l}\text { Right } \rightarrow \\
\text { Right holder } \downarrow\end{array}$ & $\begin{array}{l}\text { Composer/ } \\
\text { Lyricist }\end{array}$ & Performer & Producer \\
\hline $\begin{array}{l}\text { Reproduction on emission server } \\
\begin{array}{c}\text { Authorization of communication in } \\
\text { territory of emission }\end{array}\end{array}$ & $\mathrm{C} / \mathrm{PC} ?$ & $\mathrm{C} / \mathrm{PC} ?$ & $\mathrm{PC} ?$ \\
$\begin{array}{l}\text { Communication to the public in } \\
\text { territory of reception }\end{array}$ & $\mathrm{C}$ & $\mathrm{C} / \mathrm{R}$ & $\mathrm{C} / \mathrm{R}$ \\
$\begin{array}{l}\text { [Making available] } \\
\begin{array}{l}\text { Reproduction in territory of reception } \\
\text { nam }\end{array}\end{array}$ & $\mathrm{C} / \mathrm{PC} ?$ & $\mathrm{C} / \mathrm{R}$ \\
\hline
\end{tabular}

\section{Notes:}

C-right likely to be administered by a collective.

$\mathrm{PC}$ - use possibly covered by private copying regime.

$\mathrm{R}$-right is only to remuneration (as opposed to exclusive).

are administered separately or if multiple authors and performers are involved, the matrix would be even more complex. Naturally, there are ways in which the situation could be simplified, notably by agreements among Collective Management Organization (CMOs-see Chapter 11) that allow one participating CMO to grant a worldwide license on behalf of all other participating entities, especially with respect to the right of communication to the public. Still, one must proceed with each of the rights analyses in Table 1.1 to avoid a potential finding of infringement. In other words, the rights clearance process involves multiple layers of rights and clearing each of these rights can be a labyrinthine process even if each such process is in itself efficient. Because rights ownership and licensing arrangements change through time, the matrix becomes four-dimensional.

Rights analyses concerning audiovisual works add yet another layer of complexity to the analysis. A film might include rights to a screenplay, a book on which the screenplay was based, musical works incorporated in the film, any art or photographs used in the setting, as well as the end product of the film itself. Each of the works ${ }^{53}$ in turn involve several different rights fragments and, consequently, multiple right holders and systems of rights clearance and possibly also guilds or unions. Some right holders may have moved or died. And of course any one of the right holders who has an exclusive right may prevent the use and stop or force

53 Or object of a related right such as a sound recording. 
a rearrangement of the entire project. Each holder of a right fragment has a potential veto.

When it comes to cloud-based software, matters are even worse. The technology may in some cases reduce the number of technical uses but give some of them enormous economic importance. As Determann and Nimmer explain:

[I]n the cloud context, the one RAM copy can be accessed by multiple usersvery much unlike the desktop scenario. In the usage phase, once the cloud solution is up and running, users make access requests from remote computers. Each time the software is executed, numerous fractional excerpts of the RAM copy are reproduced in cache memory spaces and the CPU of the cloud provider's server. [....] Thus, cloud scenarios permit a far greater number of users to utilise one software copy. ${ }^{54}$

In sum, copyright fragments have lost their meaning to users and right holders alike. This is reflected in the fact that contracts and licensing arrangements for copyright works do not usually refer to the specific rights enumerated in this section or if they do, it is an afterthought. ${ }^{55}$ Contracts define the 'use' that should be allowed, and not which fragments of rights are needed. This is not borne from any malicious intent but stems from how the rights within a particular market develop over time factoring into the equation the evolution of technology.

Copyright's current structure uses an (old) regulatory model for the (new) target of online uses and of fragmented rights form the backdrop for the analysis in the chapters that follow. But first, let us take a look at the international context and applicable norms.

\footnotetext{
54 Lothar Determannn and David Nimmer, 'Software Copyright's Oracle from the Cloud' (2015) 30 Berkeley Technology Law Journal 161, 196-7.

55 A contract to allow webcasting normally refers to the function of broadcasting, independently of whether a communication to the public, one or more reproductions, or adaptations may take place. The problem is that right ownership is still by and large, especially in the area of collective management, owned by different entities based on right fragments, not actual uses of the work. While a single economic transaction should take place, several legal transactions are involved. See Al and Bob Kohn, Kohn on Music Licensing: 2000 Supplement (2nd edn, Aspen Law \& Bus 2000) 398-9.
} 